\title{
List Olega Sencowa
}

Łatwo być rewolucjonistą, gdy rewolucja już zatriumfowała. Trudno nim się stać, gdy władza ciemiężców jest wciąż silna, a szanse na sukces niewielkie. Swego czasu wielu próbowało rzucić wyzwanie największemu komunistycznemu potworowi. Węgrzy w 1956 roku - zostali zmiażdżeni przez czołgi. Potem Czesi i Słowacy w 1968 roku - ten sam wynik. Polakom w latach osiemdziesiątych się udało. Tak, wtedy imperium zła nie było już tak silne i tak krwiożercze, ale nadal bardzo negatywnie reagowało na wszelkie przejawy wolności, nawet na terytorium swoich satelitów.

Polacy jednak się zbuntowali. Nie otwarcie i nie z bronią w rękach - byłoby to niemożliwe i głupie. Zaczęli opierać się pokojowo. Spokojnie i w sposób zorganizowany, walcząc nie o lepszy kawałek chleba lub masła, ale o rzeczy ważniejsze - o prawdę i wolność. Pierwsi mieli dość życia jako niewolnicy w państwie totalnego kłamstwa. Nikt nie zna swojej przyszłości i oni wtedy też nie wiedzieli, jak to się skończy: szpitalem, więzieniem czy grobem. Ale wierzyli w sukces, robili wszystko, aby go osiągnąć, i ostatecznie zwyciężyli. Tak, obalenie potężnego imperium władającego niewolnikami bywa niemożliwe - Spartakusowi kiedyś też się to nie udało - ale kiedy nadchodzi czas i system się rozpada, można zwyciężyć. Do tego potrzebni są ludzie - ludzie, którzy się nie boją.

Uwolniwszy się z komunistycznej niewoli, Polacy - jako jedni z pierwszych - byli w stanie dołączyć do wspólnej rodziny narodów europejskich i zająć wśród nich dostojne miejsce. Tak, Unia Europejska ma teraz problemy, ale są to problemy związane z rozwojem równoprawnych partnerów, którzy swobodnie i uczciwie decydują, w jaki sposób powinni żyć i współpracować.

Jest jednak kraj, który ma teraz zupełnie inne troski. Jego przywódcy nadal myślą w kategoriach dziewiętnastowiecznych, próbując utrzymać swoje społeczeństwo w strachu i uległości. Przekonują, że wokół są wrogowie, którzy tylko marzą o tym, by zaatakować. Jednocześnie to państwo samo atakuje, zuchwale i okrutnie.

Związku Radzieckiego 2.0 z tego kraju zbudować się nie uda. Nie uda się wiecznie okłamywać swojego narodu i wszystkich wkoło. I to postimperium również upadnie, tak samo jak wszystkie podobne przed nim. Stanie się to nie tylko pod wpływem jego własnych problemów strukturalnych, ale również dlatego, że mieszkają w nim ludzie, którzy nie zgadzają się na taki stan rzeczy, którzy nie wierzą swojemu zakłamanemu państwu i chcą tylko jednego: prawdy i wolności. I oni na pewno wygrają, podobnie jak Polacy 30 lat temu, ponieważ w tej walce ich główna broń jest nadal ta sama - solidarność.
List napisany 16 sierpnia 2019 roku z kolonii karnej przez ukraińskiego reżysera, więźnia politycznego Olega Sencowa, laureata gdańskiej nagrody NEPTUN, symbolicznego patrona festiwalu Solidarity od Arts 2019. Nagrodę NEPTUN w imieniu Olega Sencowa odebrała jego kuzynka Natalia Kapłan. 